\title{
MOVERS
}

\section{Maria Betti, director, Marine Environment Laboratories, International Atomic Energy Agency, Monaco}

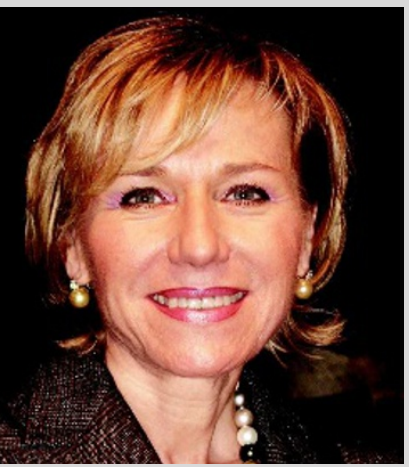

1991-2008: Head, analytical chemistry sector, Institute for Transuranium Elements, Karlsruhe, Germany 1989-91: Researcher, National Research Council, Institute of Instrumental Analytical Chemistry, Pisa, Italy 1987-90: Assistant researcher, chemistry department, University of Pisa, Italy

Maria Betti might have expected to follow her family's tradition and study language, art or literature. Instead, she opted for chemistry, biology and physics, studying the effects of pollutants on human and environmental health. She would go on to develop novel techniques to detect trace pollutants in the environment. As she assumes the directorship of the Marine Environment Laboratories at the International Atomic Energy Agency (IAEA), she says her background will help her forge new studies of the marine environment.

Fascination with algal movements in the Mediterranean Sea led Betti to a degree in marine science at the University of Pisa, in her home town. She later received a PhD in chemistry there too, investigating trace metals in marine ecosystems - part of an environmental project at a national park. There, she found her niche. "I dedicated part of my research to implementing new instrumental techniques to detect inorganic pollutants at trace levels," she says.

At the Institute of Instrumental Analytical Chemistry, part of Italy's National Research Council, Betti collaborated on research in the Antarctic Zone. Then, in 1991, she moved to the Institute for Transuranium Elements (ITU), part of the European Commission's Joint Research Centre. She says that changing her focus to the detection of radionuclides in the environment was the defining moment of her career. Since then, she has monitored the clean-up of nuclear accidents as well as analysing samples collected during United Nations inspections.

Betti's laboratory was the first civil installation in the world to use mass spectrometry in the analysis of radioactive microparticles, one of the tools used today by the IAEA and the European body Euratom to detect undeclared nuclear activities. That brought her to the attention of the IAEA and led to consulting and advisory roles there, says ITU spokesperson Gabriele Tamborini.

In her new position, Betti hopes to strengthen the links between European Union research organizations and the IAEA on a host of environmental matters. She plans to promote nuclear techniques to study the ocean, climate change and sustainable development of marine resources. For example, she hopes to use radionuclides to model phytoplankton and trace-element dynamics in the ocean an ill-defined part of the global carbon cycle.

"This position," says Betti, "is the culmination of all my scientific and human experiences over the past 25 years." Virginia Gewin

\section{NETWORKS \& SUPPORT}

\section{Counting fish}

The Fisheries Service of the US

National Oceanic and Atmospheric

Administration (NOAA) is looking for a few good fish counters. 'Stockassessment scientists' require a background in maths, computer science and/or conservation - and they are in demand.

A US government report predicts a severe shortfall in the next decade. The Shortage in the Number of Individuals with Post-Baccalaureate Degrees in Subjects Related to Fishery Science, by the departments of commerce and education, says the nation will need at least 340 scientists trained to do the research required to rebuild stocks and restore marine species - but US institutions will produce only 160.

"This can be an incredibly rewarding job. It's the interface between conservation and sustainability and policy-making," says Steven Murawski, director of scientific programmes and chief science adviser for the Fisheries Service. "You have the opportunity to make a difference." Stock assessment scientists gather data on species populations, on the basis of catches and aerial surveys. The data inform mathematical models that help predict populations under different management scenarios. This in turn helps regulators to set quotas.

The current shortfall stems from design monitoring programmes and the retirement of scientists hired in the 1960s and 1970s, from new mandates created by the US Magnuson-Stevens Fishery Conservation and Management Reauthorization Act of 2006, and from a lack of funding for academics. Whereas some scientists bring in millions of federal dollars, stockassessment scientists bring in a couple of thousand from NOAA. "It's been an easy choice [for universities]," says Jim Berkson, a unit leader for the Fisheries Service. "But we're trying to make the point that this is a growth industry and it will bring in money."

Commercial fishermen want more stock-assessment scientists on deck to forestall outdated quotas. Jim

Ruhle, president of Commercial Fishermen of America, cites a 2004 butterfish quota based on 2002 data.

Larry Alade, a stock-assessment scientist and research fisheries biologist with the Fisheries Service at Woods Hole, Massachusetts, says he routinely draws on his background in computer science, biology and maths. After a master's in computer science and internships at a Mississippi fishery stock-assessment programme and at Woods Hole, Alade did a PhD in marine estuary and environmental sciences. He's now got a job he loves - contributing to sustainability. Karen Kaplan

\section{POSTDOC JOURNAL}

\section{One-man team}

In the fossil record they call it punctuated equilibrium. You just blink and, wham a species appears in a bedding plane. This is my current bedtime reading. I selected it for its research relevance, but it's quickly becoming a page turner with familiar characters whose situation I can relate to. Were the first few pioneer individuals of a species intimidated by the big ecological niche waiting to be conquered? As I move to my new lecturer position, I ponder this with some empathy.

"Whose group are you working for?" is becoming a common question when I meet new faces at coffee time. It's as if they're asking, "So what species are you?" My reply: "My own." For the first time in my career I am not starting a job as part of a research team. I'm starting alone. Of course I still have distant collaborations, but nothing nearby. My group must grow if it is to persist. Growth needs funding, and funding calls have deadlines -32 days to go in my case. So I'm considering some ideas and meeting the locals and their research interests, face to face. Either I go it alone with my existing collaborators, or establish a new, joint project with researchers in my new department. The latter sounds good, but have I got time? I suspect it's a rate of adaptation that few of my fossilized friends would have had to endure. Jon Yearsley is now a lecturer at University College Dublin, Ireland. 